\title{
Copper Corrosion by Atmospheric Pollutants in the Electronics Industry
}

\author{
Benjamin Valdez Salas, ${ }^{1}$ Michael Schorr Wiener, ${ }^{1}$ \\ Roumen Zlatev Koytchev, ${ }^{1}$ Gustavo López Badilla, ${ }^{2}$ Rogelio Ramos Irigoyen, ${ }^{1}$ \\ Monica Carrillo Beltrán, ${ }^{1}$ Nicola Radnev Nedev, ${ }^{1}$ Mario Curiel Alvarez, \\ Navor Rosas Gonzalez, ${ }^{2}$ and Jose María Bastidas Rull ${ }^{3}$ \\ ${ }^{1}$ Engineering Institute, Autonomous University of Baja California, Boulevard Benito Juarez y Calle a la Normal S/N, \\ Colonia Insurgentes Este, 21280 Mexicali, BCN, Mexico \\ ${ }^{2}$ Polytechnic University of Baja California, Calle de la Claridad S/N, Colonia Plutarco Elias Calles, 21376 Mexicali, BCN, Mexico \\ ${ }^{3}$ National Center of Metallurgical Research, Avenue Gregorio del Amo 8, 28040 Madrid, Spain \\ Correspondence should be addressed to Benjamin Valdez Salas; benval@uabc.edu.mx
}

Received 10 July 2013; Accepted 23 August 2013

Academic Editors: L. Bazzi, G. Bereket, and A. Hermann

Copyright ( 2013 Benjamin Valdez Salas et al. This is an open access article distributed under the Creative Commons Attribution License, which permits unrestricted use, distribution, and reproduction in any medium, provided the original work is properly cited.

Hydrogen sulphide $\left(\mathrm{H}_{2} \mathrm{~S}\right)$ is considered one of the most corrosive atmospheric pollutants. It is a weak, diprotic, reducing acid, readily soluble in water and dispersed into the air by winds when emitted from natural, industrial, and anthropogenic sources. It is a pollutant with a high level of toxicity impairing human health and the environment quality. It attacks copper forming thin films of metallic sulphides or dendrite whiskers, which are cathodic to the metal substrate, enhancing corrosion. $\mathrm{H}_{2} \mathrm{~S}$ is actively involved in microbially influenced corrosion (MIC) which develops in water, involving sulphur based bacteria, in oxidizing and reducing chemical reactions. $\mathrm{H}_{2} \mathrm{~S}$ is found in concentrated geothermal brines, in the atmosphere of geothermal fields, and in municipal sewage systems. Other active atmospheric pollutants include $\mathrm{SO}_{X}, \mathrm{NO}_{X}$, and CO. This investigation reports on the effects of $\mathrm{H}_{2} \mathrm{~S}$ on copper in microelectronic components of equipment and devices, with the formation of nonconductive films that lead to electrical failures.

\section{Introduction}

The electronics industry is spread out worldwide; it is an important sector in the Mexican economy, representing $80 \%$ of industrial companies in the northwest of the country. Their assembly plants are located in three cities: Mexicali, an arid zone, Tijuana, an urban-industrial area, and Ensenada, a marine region on the Pacific Ocean coast, all belonging to the State of Baja California, near the Mexico-USA border. The electronics industry appeared in Mexico during the sixties with the manufacture of electronic products such as radios, audio record and play devices, and televisions. This industry designs and manufactures microelectronic components called microcontrol devices (MCD), integrated with microelectromechanical systems (MEMS). A study was conducted in the indoor areas of three electronics plants in these cities. Copper and its alloys are widely applied in the electric energy, electronics, and semiconductor industries because of their high electrical and thermal conductivity, ductility, and malleability.

Copper is considered a noble metal; it resists attack by oxygen, although some air pollutants, such as $\mathrm{H}_{2} \mathrm{~S}$, change its surface properties, even at ambient temperature, forming a thin layer having completely different properties compared with the pure metal surface. This layer lowers catastrophically the adhesion of the soldering alloy or conductive resins and paste, provoking failures of the printed circuit board (PCB) of the microelectronic devices. Compounds such as 
geerite $\left(\mathrm{Cu}_{8} \mathrm{~S}_{5}\right)$ are formed on $\mathrm{Cu}$ in the presence of $\mathrm{H}_{2} \mathrm{~S}$ and patinas as $\mathrm{Cu}_{2} \mathrm{O}$; posnjakite $\left(\mathrm{Cu}_{4} \mathrm{SO}(\mathrm{OH})_{6} \mathrm{H}_{2} \mathrm{O}\right)$, brochantite $\left(\mathrm{Cu}_{4} \mathrm{SO}_{4}(\mathrm{OH})_{6} \mathrm{H}_{2} \mathrm{O}\right)$, and antlerite $\left(\mathrm{Cu}_{3} \mathrm{SO}_{4}(\mathrm{OH})_{4}\right)$ are formed in the presence of humidity [1]. The formation of tarnish films on a copper surface exposed to environments containing atmospheric pollutants and high humidity involves the movement of metallic ions over the surface, away from the metal generating a creep process that increases the contact resistance, leading to electric failures of the electronic devices. Copper sulphidation is a fast process occurring on the metal-gas phase interface impairing the $\mathrm{Cu}$ corrosion resistance $[2,3]$. This paper presents the corrosion process of $\mathrm{Cu}$ exposed to $\mathrm{H}_{2} \mathrm{~S}$ polluted environments, under varied conditions of temperature and humidity, in the indoor areas of electronics manufacturing plants located in Mexicali, Baja California, Mexico [4].

\section{2. $\mathrm{H}_{2} \mathrm{~S}$, a Corrosive, Toxic Pollutant}

It is appropriate to report in the context of the present paper about the corrosivity and toxicity of $\mathrm{H}_{2} \mathrm{~S}$ since this also affects the quality of the environment, human health, and the durability of the engineering materials, which are central issues of modern society. $\mathrm{H}_{2} \mathrm{~S}$ acts as a pollutant in the indoor areas of manufacturing plants of the electronics industry; it promotes the formation of thin copper sulphide films on PCB surfaces. Recent investigations $[5,6]$ proved that the main $\mathrm{H}_{2} \mathrm{~S}$ source is a geothermal field generating underground sources of steam and $\mathrm{H}_{2} \mathrm{~S}$ located about $40 \mathrm{~km}$ south from Mexicali city. To avoid this air pollution and consequent corrosion is impossible without the application of high cost air cleaners $[7,8]$.

$\mathrm{H}_{2} \mathrm{~S}$ gas emitted into the atmosphere from additional heavy sources such as municipal sewage causes respiratory diseases and inflammation of the eyes; it has an offensive odor of rotten eggs; therefore, it is easy to detect, even at low concentration of 10 to $30 \mathrm{ppb}$ (parts per billion) in the atmosphere around the geothermal fields.

The corrosion activity of $\mathrm{H}_{2} \mathrm{~S}$ is evident in

$$
\begin{aligned}
& \mathrm{Fe}+\mathrm{H}_{2} \mathrm{~S} \longrightarrow \mathrm{FeS}+\mathrm{H}_{2} \\
& \mathrm{Cu}+\mathrm{H}_{2} \mathrm{~S} \longrightarrow \mathrm{CuS}+\mathrm{H}_{2}
\end{aligned}
$$

\section{Experimental}

3.1. Air Pollutants Measurements. Data on air pollutants were gathered every five minutes and organized in files for monthly periods. The specialized instruments controlled by the United States Environmental Protection Agency (US-EPA) monitoring air pollution were a chemiluminescence $\mathrm{NO}_{X}$ analyzer, model 42 of Thermo Environmental Instruments Inc., a gas filter $\mathrm{CO}$ analyzer model 3000E of Advanced Pollution Instruments Inc., (API), a $\mathrm{SO}_{2}$ photometric analyzer from Thermo Electron Corporation, and an $\mathrm{O}_{3}$ analyzer model 400 of API. This electronic instrument has filters to separate dust particles from gases.

The practices recommended in ISO standards for atmospheric corrosion were taken into account. The Cerro Prieto geothermal wells, in the vicinity of Mexicali, emit $\mathrm{H}_{2} \mathrm{~S}$ into the atmosphere surrounding the fields and the power plants. Other $\mathrm{H}_{2} \mathrm{~S}$ emissions came from the plant chimney stacks, vapour ducts, noise silencers, and cooling towers, totaling $22,740 \mathrm{t}$ per year $[9,10]$. Since the production capacity of Cerro Prieto has not changed over the last 5 years or so, it may be estimated that the same $\mathrm{H}_{2} \mathrm{~S}$ concentration in the atmosphere, around the geothermal wells, ranges from 10 to $30 \mathrm{ppb}$. Typical ranges of natural and anthropogenic $\mathrm{H}_{2} \mathrm{~S}$ under outdoor and indoor conditions are $0.724 \mathrm{ppb}$ and 0.1 to $0.7 \mathrm{ppb}$, respectively $[11,12]$.

3.2. Corrosion Rate Measurement. Rectangular metallic specimens of $\mathrm{Cu}$ with an exposition surface of $6.45 \mathrm{~cm}^{2}$ were prepared. The specimens were polished to $400 \mathrm{SiC}$ paper, washed, degreased with acetone, dried with hot air, and weighed before being installed in a metallic chamber of exposure under indoor conditions for 1-, 3-, 6-, 12- and 24-month periods. The corrosion rates were determined by applying the gravimetric method according to ASTM G 31 standard method. In order to simulate controlled indoor conditions, the chamber was fabricated with precoated aluminum with a total volume of $0.1 \mathrm{~m}^{3}$ and conditioned with two air inlet blinds coupled to metallic filters in order to permit the penetration of gases with the flow of air, to prevent the penetration of dust, and to avoid mistakes in the weight loss calculations $[13,14]$. The chamber was provided with metallic internal supports to hold the specimens; it was installed on the roof of an electronics manufacturing plant at $10 \mathrm{~m}$ above ground level $[15,16]$.

After each period of exposure, the metallic samples were removed and weighed to obtain the mass gain. The corrosion products morphology was observed with a stereoscope before being removed, cleaned, and reweighed to obtain the mass loss on an analytical balance to the nearest $.00001 \mathrm{~g}$ of accuracy. Corrosion of $\mathrm{Cu}$ surfaces under constant concentration of $\mathrm{H}_{2} \mathrm{~S}$ and controlled relative humidity $(\mathrm{RH})$ conditions occurred using a closed system consisting of an acrylic sealed chamber with an inlet valve in order to provide a $0.1 \mathrm{ppm}$ $\mathrm{H}_{2} \mathrm{~S}$ concentration and a ventilator coupled to a humidity generator to provide $80 \% \mathrm{RH}[17,18]$.

3.3. Surface Examination. The copper specimens exposed to a controlled $\mathrm{H}_{2} \mathrm{~S}$ environment during short times were analyzed to determine their surface characteristics by a Scanning Electron Microscopy (SEM) applying a JEOL (JEOL, Ltd., Peabody, MA) JSM-6360, coupled with an Energy Dispersive X-ray (EDX) analyzer (AMETEK, Inc., Mahwah, NJ), used for chemical composition analysis.

\section{Results}

4.1. Corrosion of Copper. The corrosion rate (CR) of $\mathrm{Cu}$ specimens exposed in the test chamber during 24 months (Figure 1) demonstrates that the extent of corrosion augments with the exposure time reaching values of $270 \mathrm{mg} \cdot \mathrm{m}^{-2}$ after the two years of exposure at $\mathrm{RH}$ values ranged from $15 \%$ to $75 \%$ and temperatures from $4^{\circ} \mathrm{C}$ to $45^{\circ} \mathrm{C}$, depending on 


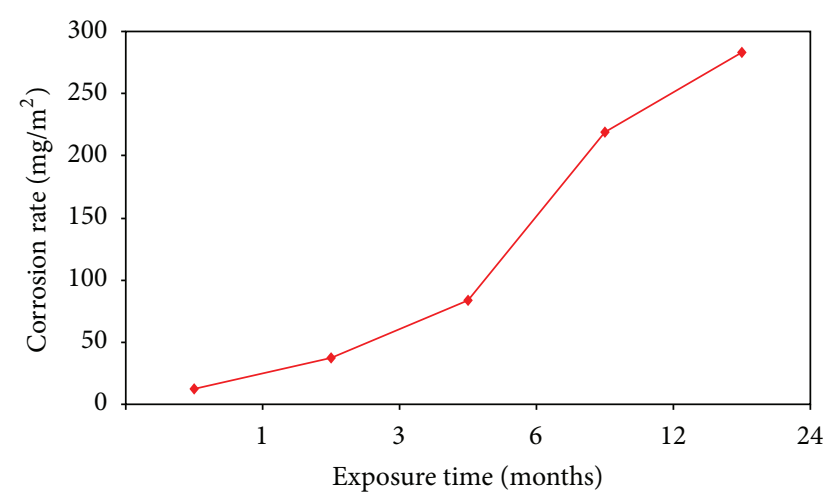

FIGURE 1: Corrosion rate of copper exposed in the corrosion chamber during 24 months.

TABLE 1: Copper sulphides in films formed by reaction with $\mathrm{H}_{2} \mathrm{~S}$ at indoor areas of electronics plants in Mexicali City.

\begin{tabular}{lc}
\hline Mineral & Chemical composition \\
\hline Chalcocite & $\mathrm{Cu}_{2} \mathrm{~S}$ \\
Djurlcite & $\mathrm{Cu}_{1.95} \mathrm{~S}$ \\
Digenite & $\mathrm{Cu}_{1.82} \mathrm{~S}$ \\
Geerite & $\mathrm{Cu}_{1.62} \mathrm{~S}$ \\
\hline
\end{tabular}

the year season; $\mathrm{SO}_{2}$ and $\mathrm{NO}_{X}$ were the species with major concentration levels.

Corrosion of $\mathrm{Cu}$ in the presence of air, $\mathrm{H}_{2} \mathrm{~S}$, and humidity produces oxides and/or sulphides as wet films leading to electrical failures in electronic equipment [10]. On the other hand, corrosion of $\mathrm{Cu}$ occurs when the $\mathrm{RH}$ overpasses the $80 \%$ and the $\mathrm{SO}_{2}$ concentration is larger than $0.1 \mathrm{ppm}$. The corrosion behavior also depends on the state of the metal surface: smooth, corrugated, polished, and nonuniform. Sometimes, a $\mathrm{Cu}_{2} \mathrm{O}$ film that slows the rate of corrosion gradually dissolves in the presence of an acidic electrolyte constituted by $\mathrm{SO}_{2}$, and then the corrosion products formed are different due to the surface conditions. At levels of $\mathrm{SO}_{2}$ greater than the air quality standards, in combination with $\mathrm{NO}_{2}$ and $\mathrm{O}_{3}$ at different concentrations in indoor plants, cuprite $\left(\mathrm{Cu}_{2} \mathrm{O}\right)$ and copper sulphides form, as depicted in Figures 2 and 3.

Some spectacular structures of hexagonal crystals of $\mathrm{Cu}$ sulphide are shown in Figure 3. The SEM results of the exposed samples showed the formation of spots of $\mathrm{CuS}$ during the first two days, which grew continuously until all spots united together as large films covering the entire sample surface. The concentration of $\mathrm{H}_{2} \mathrm{~S}$ in the electronics plant atmosphere was $0.9 \mathrm{ppm}$; at the Cerro Prieto geothermal field atmosphere it reaches $1.5 \mathrm{ppm}$ and higher concentrations, due to the continuous emission of gases accompanying the produced steam [11].

The EDX analysis performed in different points of the corroded copper surfaces reveals the formation of several sulphides of stoichiometric composition with a general formula $\mathrm{Cu}_{X} \mathrm{~S}$, where the values of $X$ vary from 1.6 to 2 . The estimated

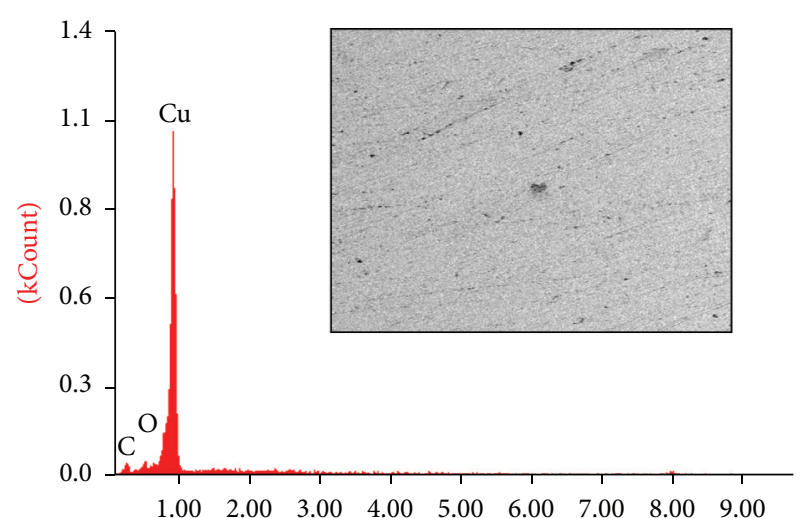

FIGURE 2: SEM picture for Cu surface after 2 days in $0.3 \mathrm{ppm}_{2} \mathrm{~S} /$ air, magnification 400x.

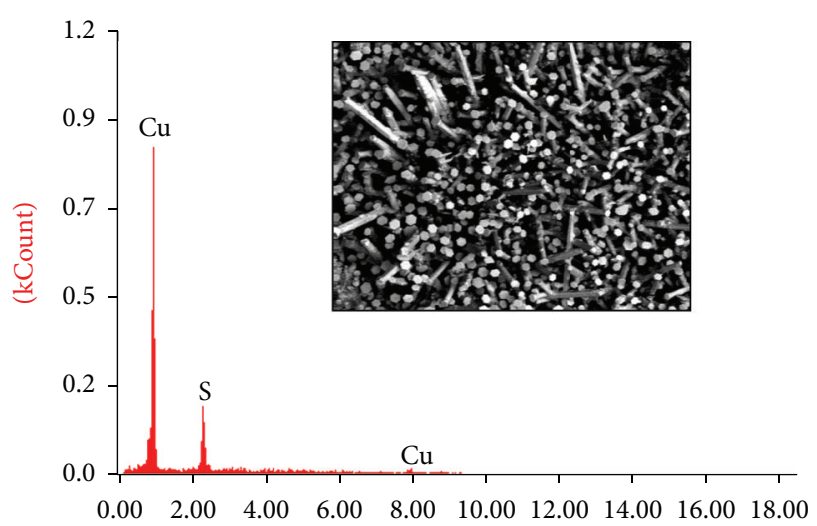

FIGURE 3: SEM picture for Cu surface after 2 days in $0.3 \mathrm{ppm}_{2} \mathrm{~S} /$ air, magnification 1200x.

composition of the copper sulphide corrosion products and the corresponding mineral are displayed in Table 1.

4.2. Film Formation Mechanisms. Under conditions of humidity and in contact with air contaminated with $\mathrm{H}_{2} \mathrm{~S}, \mathrm{Cu}$ generates two types of corrosion products: oxides and sulphides according to the following electrochemical reactions.

Oxidation

$2 \mathrm{Cu} \longrightarrow 2 \mathrm{Cu}^{2+}+4 \mathrm{e}^{-}$

Oxidation, anodic reaction

$\mathrm{O}_{2}+2 \mathrm{H}_{2} \mathrm{O}+4 \mathrm{e}^{-} \longrightarrow 4 \mathrm{OH}^{-}$

Reduction, cathodic reaction

$2 \mathrm{Cu}+\mathrm{O}_{2}+2 \mathrm{H}_{2} \mathrm{O} \longrightarrow 2 \mathrm{Cu}(\mathrm{OH})_{2}$

Total corrosion reaction

$2 \mathrm{Cu}(\mathrm{OH}) \longrightarrow \mathrm{Cu}_{2} \mathrm{O}+\mathrm{H}_{2} \mathrm{O}$

Hydroxide converts to oxide 
Correlation of $\mathrm{Cl}$ of $\mathrm{H}_{2} \mathrm{~S}$ with climatic factors in summer

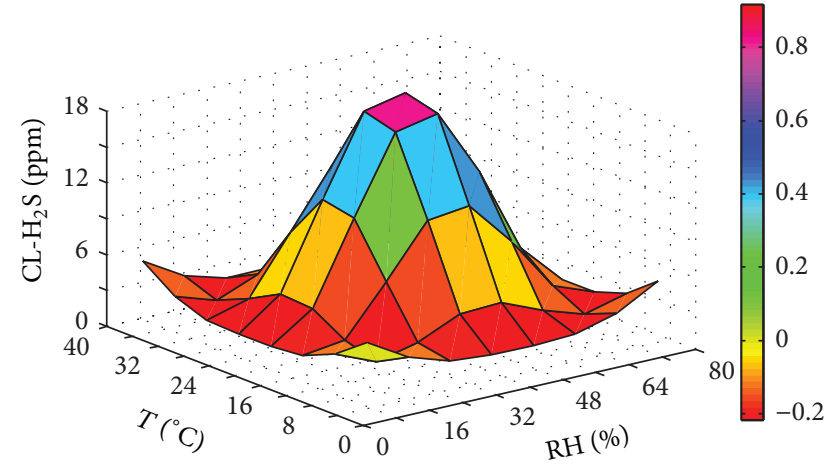

FIgURE 4: Correlation of copper corrosion with $\mathrm{H}_{2} \mathrm{~S}$, relative humidity \%, and temperature in the electronics industry (summer, 2010).

\section{Sulphidation}

$\mathrm{Cu} \longrightarrow \mathrm{Cu}^{2+}+2 \mathrm{e}^{-}$

Oxidation, anodic reaction

$\mathrm{H}_{2} \mathrm{~S} \longrightarrow \mathrm{H}^{+}+\mathrm{SH}^{-}$

Reduction, cathodic reaction

$2 \mathrm{SH}^{-} \longrightarrow 2 \mathrm{~S}^{-}+\mathrm{H}_{2}$

Reduction, cathodic reduction

$\mathrm{Cu}+\mathrm{H}_{2} \mathrm{~S} \longrightarrow \mathrm{CuS}+\mathrm{H}_{2}$

Total sulphidation reaction.

4.3. Influence of Atmospheric Pollutants. Mexicali city has highly contaminated air because of the presence of fine dust coming from the desert around, but the gaseous pollutants such as $\mathrm{SO}_{X}, \mathrm{NO}_{X}, \mathrm{CO}$, and $\mathrm{O}_{3}$ are generated from the diverse industrial activities. Air pollutants penetrate to indoor locations of electronics plants and corrode $\mathrm{Cu}$-made devices. The relative humidity $(\mathrm{RH})$ and temperature reach up to $50 \%$ and $30^{\circ} \mathrm{C}$ during the major part of the year. Table 2 presents the relation between the concentrations of these pollutants and the Mexicali climatic factors. The two most aggressive pollutants are sulphur-containing $\mathrm{H}_{2} \mathrm{~S}$ and $\mathrm{SO}_{2}$, both acidic, but one reducing $\left(\mathrm{H}_{2} \mathrm{~S}\right)$ and the other oxidant $\left(\mathrm{SO}_{2}\right)$ agents. Their behaviour and corrosivity during the seasons of the year are presented in Table 3.

The corrosion data collected, arranged in Tables 2 and 3 , correlate values of $\mathrm{RH}$, temperature, and $\mathrm{CR}$ provoked by the different atmospheric pollutants. These data were evaluated and displayed using the MATLAB software, a mathematical computing software (MathWorks Inc., USA), to determine the relationship between the environmental factors and the corrosion rate of metals used in the electronics industry. Figure 4 is a particular $3 \mathrm{D}$ graph depicting the correlation of
Correlation of corrosivity levels with atmospheric pollution

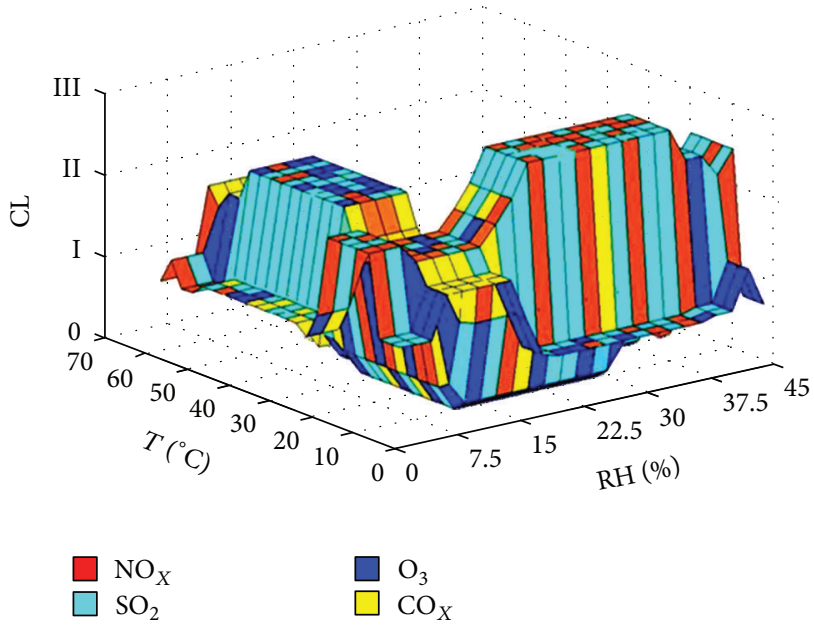

FIGURE 5: Correlation of climatic factors and pollutants with corrosivity indexes.

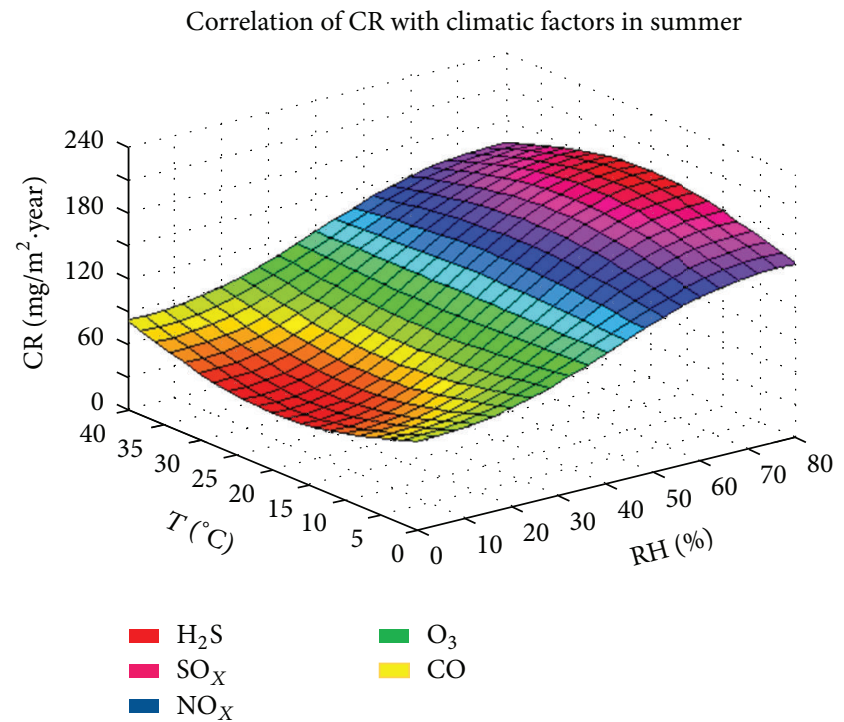

FIgURE 6: Correlation of CR of copper with climatic factors in summer in Mexicali (2010).

the $\mathrm{CR}$ of $\mathrm{Cu}$ with the $\mathrm{RH}$ and the temperature, indicating in circles the maximum and the minimum CR.

The maximum $\mathrm{CR}$ appears at $88 \% \mathrm{RH}$ and $16^{\circ} \mathrm{C}$ and the minimum $\mathrm{CR}$ is recorded at $18 \% \mathrm{RH}$ and $2.0^{\circ} \mathrm{C}$, expressing the critical influence of humidity and temperature levels. These levels are controlled inside the electronics plant but sometimes corrosion occurs.

An additional MATLAB graph depicts the influence of frequent industrial pollutants: $\mathrm{NO}_{X}, \mathrm{SO}_{X}, \mathrm{O}_{3}$, and $\mathrm{CO}_{X}$ on the corrosivity indexes of $\mathrm{Cu}$ published by ISO, the International Organization for Standardization [7] (Figure 5).

Other MATLAB graphs correlate the $\mathrm{CR}$ of $\mathrm{Cu}$ with the climatic factors and pollutants in summer 2010 in Mexicali (Figure 6) and those in winter 2010 too (Figure 7). 
TABLE 2: Relation of concentration of air pollutants and climate factors in Mexicali.

\begin{tabular}{|c|c|c|c|c|c|c|c|c|c|c|c|c|}
\hline \multirow{3}{*}{ Seasons } & \multicolumn{12}{|c|}{ Climatic factors } \\
\hline & \multicolumn{3}{|c|}{ Sulfur dioxide $\left(\mathrm{SO}_{2}\right)$} & \multicolumn{3}{|c|}{ Carbon monoxide (CO) } & \multicolumn{3}{|c|}{ Nitrogen oxides $\left(\mathrm{NO}_{X}\right)$} & \multicolumn{3}{|c|}{ Ozone $\left(\mathrm{O}_{3}\right)$} \\
\hline & $\mathrm{RH}^{\mathrm{a}}$ & $T^{\mathrm{b}}$ & $C^{\mathrm{c}}$ & $\mathrm{RH}^{\mathrm{a}}$ & $T^{\mathrm{b}}$ & $C^{\mathrm{c}}$ & $\mathrm{RH}^{\mathrm{a}}$ & $T^{\mathrm{b}}$ & $C^{\mathrm{c}}$ & $\mathrm{RH}^{\mathrm{a}}$ & $T^{\mathrm{b}}$ & $C^{\mathrm{c}}$ \\
\hline \multicolumn{13}{|l|}{ Spring } \\
\hline $\operatorname{Max}$ & 49.3 & 34.8 & 0.16 & 39.1 & 29.3 & 69 & 34.3 & 28.6 & 0.48 & 48.3 & 27.3 & 0.21 \\
\hline Min & 23.3 & 20.4 & 0.08 & 28.6 & 22.1 & 4 & 29.8 & 19.9 & 0.01 & 28.5 & 15.2 & 0.06 \\
\hline \multicolumn{13}{|l|}{ Summer } \\
\hline $\operatorname{Max}$ & 83.8 & 45.9 & 0.11 & 73.9 & 45.9 & 57 & 70.8 & 39.9 & 0.54 & 73.2 & 44.5 & 0.37 \\
\hline Min & 46.1 & 23.6 & 0.03 & 47.5 & 29.2 & 16 & 44.7 & 22.4 & 0.18 & 44.3 & 26.5 & 0.01 \\
\hline \multicolumn{13}{|l|}{ Winter } \\
\hline $\operatorname{Max}$ & 77.8 & 27.4 & 0.50 & 72.8 & 24.7 & 84 & 69.1 & 24.6 & 0.75 & 87.9 & 27.7 & 0.51 \\
\hline Min & 16.6 & 17.8 & 0.17 & 39.3 & 23.9 & 6 & 63.2 & 13.8 & 0.17 & 47.2 & 28.8 & 0.05 \\
\hline
\end{tabular}

${ }^{\mathrm{a}} \mathrm{RH}$ : relative humidity, $\%,{ }^{\mathrm{b}} \mathrm{T}$ : temperature, ${ }^{\circ} \mathrm{C}$, and ${ }^{\mathrm{c}} \mathrm{C}$ : air pollution concentration $(C), \mathrm{ppm}$.

TABLE 3: Correlation of corrosion rate, the year season, and air pollutants in indoor conditions of industrial plants.

\begin{tabular}{|c|c|c|c|c|c|c|c|c|}
\hline \multirow{3}{*}{ Seasons } & \multicolumn{8}{|c|}{ Climatic factors } \\
\hline & \multicolumn{4}{|c|}{ Hydrogen sulfide $\left(\mathrm{H}_{2} \mathrm{~S}\right)$} & \multicolumn{4}{|c|}{ Sulfur dioxide $\left(\mathrm{SO}_{2}\right)$} \\
\hline & $\mathrm{RH}^{\mathrm{a}}$ & $T^{\mathrm{b}}$ & $C^{\mathrm{c}}$ & $\mathrm{CR}^{\mathrm{d}}$ & $\mathrm{RH}^{\mathrm{a}}$ & $T^{\mathrm{b}}$ & $C^{\mathrm{c}}$ & $\mathrm{CR}^{\mathrm{d}}$ \\
\hline \multicolumn{9}{|l|}{ Spring } \\
\hline $\operatorname{Max}$ & 88.8 & 33.4 & 0.15 & 255 & 85.6 & 23.2 & 0.34 & 176 \\
\hline Min & 34.5 & 17.6 & 0.09 & 130 & 46.7 & 15.1 & 0.23 & 112 \\
\hline \multicolumn{9}{|l|}{ Summer } \\
\hline Max & 89.9 & 42.1 & 0.14 & 265 & 88.2 & 39.9 & 0.45 & 245 \\
\hline Min & 38.5 & 24.3 & 0.11 & 181 & 42.3 & 28.2 & 0.18 & 114 \\
\hline \multicolumn{9}{|l|}{ Winter } \\
\hline $\operatorname{Max}$ & 87.5 & 25.6 & 0.42 & 382 & 88.8 & 22.3 & 0.67 & 338 \\
\hline Min & 43.2 & 17.8 & 0.26 & 245 & 38.9 & 12.3 & 0.25 & 136 \\
\hline
\end{tabular}

${ }^{\mathrm{a}} \mathrm{RH}$ : relative humidity, $\%,{ }^{\mathrm{b}} \mathrm{T}$ : temperature, ${ }^{\circ} \mathrm{C},{ }^{\mathrm{c}} \mathrm{C}$ : air pollution concentration $(C)$, ppm, and ${ }^{\mathrm{d}} \mathrm{CR}$ : corrosion rate, $\mathrm{mg} / \mathrm{m}^{2} \cdot$ year.

\section{Discussion}

The climatic variables and the atmospheric pollutants are the principal factors that enhance the corrosion in indoor conditions of the metals utilized in the electronics industry of the State of Baja California, Mexico. The evaluation of these parameters and their effect on the metals' surfaces demonstrates the relationship of atmospheric corrosion with the damage caused to the electrical connections, resistors, diodes, connectors, and wires of the electrical-electronic equipment. This corrosion damage generates low yielding by electrical failures in the industrial devices and equipment. The maximum and minimum $\mathrm{RH}$, temperature, and $\mathrm{CR}$ and the relationship with the air pollutants were analyzed during different seasons of the year. These data were expressed graphically applying the MATLAB software. A study on the correlation of climate factors with the function of electronic test equipment installed inside a clean room of an electronics plant in the city of Tijuana was conducted; it was done at various levels of RH and temperature, relating them to the electric current circulating in the test equipment to indicate the correct or incorrect state of the microcomponents. They include electronic components such as transistors, capacitors, coils, resistors, and diodes that are assembled in the semiconductor wafer based on a silicon microelectronic board. The bad air quality in Tijuana should be attributed to the last cold winters that have caused more burning of fossil fuels to supply electricity for urban-heating systems, increasing the emissions of corrosive pollutants, worsening the smog which comprises fire smoke, car exhaust gases, and dust, all trapped in the air mist. The health impact is vast too, raising the number of people suffering from respiratory illness that triggers heart and asthma attacks. The city of Ensenada is located on the coast of the Pacific Ocean, in the northwest of Mexico in a marine region. It has a tropical marine climate with cold winter mornings around $5^{\circ} \mathrm{C}$ and $35^{\circ} \mathrm{C}$ in the summer; $\mathrm{RH}$ is around $20 \%$ to $80 \%$, varying during the seasons of the year. The climate factors analyzed were humidity, temperature, winds, and rains to determine the time of wetness (TOW), a critical factor in the determination of CR and its extent.

Santa Ana winds (SAW) constitute a climatic phenomenon that alters the atmospheric conditions; they originate in the Santa Ana canyon, in the Mojave desert, which 
Correlation of CR with climatic factors in winter

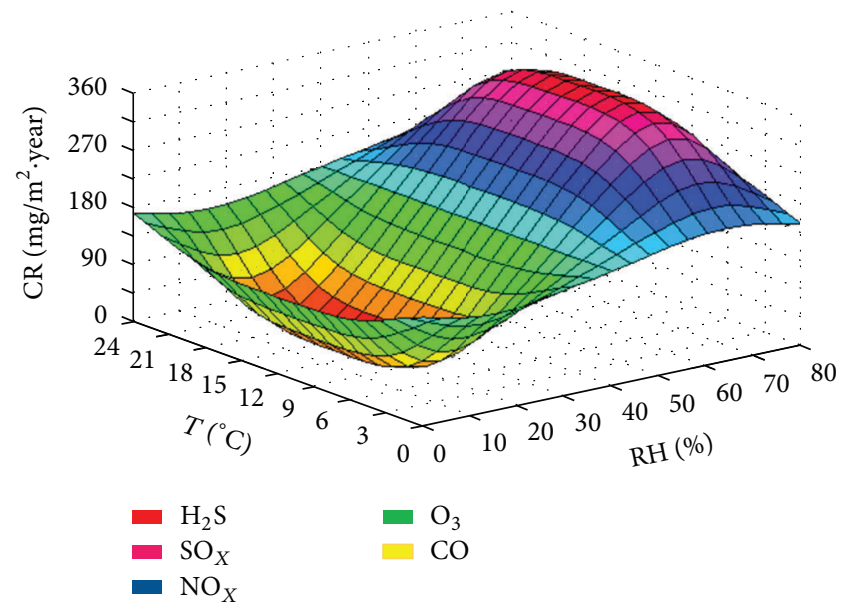

FIGURE 7: Correlation of CR of copper with climatic factors in winter in Mexicali (2010).

cause fast changes in the climate conditions in southwest California and northwest Baja California. SAW form when the desert becomes cooler, usually during the autumn and spring seasons; rising temperatures, humidity, and meteorological conditions influence the indoor environment of the electronics industry. The principal air corrodent encountered in Ensenada is the $\mathrm{NaCl}$ aerosols from the sea, in addition to $\mathrm{CO}, \mathrm{NO}_{X}$ and $\mathrm{SO}_{2}$ from traffic vehicles, power stations, and industrial and landfill emissions which increase atmospheric corrosivity $[13,14]$.

\section{Conclusions and Recommendations}

A study was conducted during a span of two years on the corrosion of metallic materials used in the manufacture of electronic devices and equipment. The gaseous air pollutants, for example, $\mathrm{H}_{2} \mathrm{~S}, \mathrm{SO}_{X}, \mathrm{NO}_{X}$, and $\mathrm{CO}$, generated by the geothermal fields, the electricity industry, and the motor vehicles burning fossil fuels, lead to the appearance of corrosion on the metals' surfaces. Copper suffers in particular due to the attack by sulphur-containing pollutants: $\mathrm{H}_{2} \mathrm{~S}$ and $\mathrm{SO}_{X}$ forming copper sulphides and oxides that impair their electrical conductivity properties. The installation and effective maintenance systems, to clean and control the contaminated air that infiltrates into the electronics production rooms such as filters would prevent and/or minimize this atmospheric corrosion. Encapsulation and hermetic sealing of microcomponents prevent a reaction with the pollutants. Removal of moisture by efficient air conditioning and continuous maintenance of an optimum environmental condition of the indoor areas of electronics plants avoids and/or mitigates corrosion.

\section{Conflict of Interests}

The authors of this paper declare not to have any direct or indirect financial relation with the commercial identity mentioned in the paper that might lead to a conflict of interest for any of them.

\section{References}

[1] B. Valdez, M. Schorr, M. Quintero et al., "Corrosion and scaling at Cerro Prieto geothermal field," Anti-Corrosion Methods and Materials, vol. 56, no. 1, pp. 28-34, 2009.

[2] L. Veleva, B. Valdez, G. Lopez, L. Vargas, and J. Flores, "Atmospheric corrosion of electro-electronics metals in urban desert simulated indoor environment," Corrosion Engineering Science and Technology, vol. 43, no. 2, pp. 149-155, 2008.

[3] J. F. Flores and S. B. Valdez, "Cabina de simulación de corrosion para la industria electrónica en interior," Ingenieros, vol. 6, no. 21, 2003 (Spanish).

[4] ASTM, "Standard practice for conducting atmospheric corrosion test on metals," ASTM G50-76, ASTM, West Conshohocken, Pa, USA, 2003.

[5] G. Lopez, B. Valdez, and M. Schorr, "Spectroscopy analysis of corrosion in the electronics industry influenced by Santa Ana Winds in marine environments of Mexico," in Indoor and Outdoor Air Pollution, INTECH, 2011.

[6] "Corrosion of metals and alloys. Classification of low corrosivity of indoor atmospheres: determination and estimation attack in indoor atmospheres," ISO 11844-1, ISO, Geneva, Switzerland, 2005.

[7] "Corrosion of metals and alloys. Classification of low corrosivity of indoor atmospheres: determination and estimation of indoor corrosivity," ISO 11844-2, ISO, Geneva, Switzerland, 2006.

[8] A. Moncmanova, Environmental Deterioration of Materials, WIT Press, 2007.

[9] L. B. Gustavo, Caracterización de la corrosión en materiales metálicos de la industria electrónica en Mexicali, B.C. [Tesis de doctorado], UABC, Instituto de Ingeniería, Mexicali, México, 2008.

[10] G. López, H. Tiznado, G. Soto, W. de la Cruz, B. Valdez, and R. M. Schorr Zlatev, "Corrosión de dispositivos electrónicos por contaminación atmosférica en interiores de plantas de ambientes áridos y marinos," Revista Nova Scientia, vol. 3, no. 1, 2010.

[11] G. López, H. Tiznado, G. S. Herrera et al., "Use of AES in corrosion of copper connectors of electronic devices and equipments in arid and marine environments," Anti-Corrosion Methods and Materials, vol. 58, no. 6, pp. 331-336, 2011.

[12] M. Reid, J. Punch, C. Ryan et al., "Microstructural development of copper sulfide on copper exposed to humid $\mathrm{H}_{2} \mathrm{~S}$," Journal of the Electrochemical Society, vol. 154, no. 4, pp. C209-C214, 2007.

[13] B. Valdez, M. Schorr, R. Zlatev et al., "Corrosion control in industry," in Environment and Industrial Corrosion, Practical and Theoretical Aspects, INTECH, 2012.

[14] S. B. Valdez, W. M. Schorr, B. G. Lopez et al., " $\mathrm{H}_{2} \mathrm{~S}$ pollution and its effect on corrosion of electronic components," in Air QualityNew Perspective, INTECH, 2012.

[15] B. G. Lopez, S. B. Valdez, W. M. Schorr, and G. C. Navarro, "Microscopy and spectroscopy of MEMS used in the electronic industry of Baja California region Mexico," in Air Quality-New Perspective, INTECH, 2012.

[16] B. G. Lopez, S. B. Valdez, K. R. Zlatev, P. J. Flores, B. M. Carrillo, and W. M. Schorr, "Corrosion of metals at indoor conditions in the electronics manufacturing industry," Anti-Corrosion Methods and Materials, vol. 54, no. 6, pp. 354-359, 2007. 
[17] J. Smith, Z. Qin, F. King, L. Werme, and D. W. Shoesmith, "Sulfide film formation on copper under electrochemical and natural corrosion conditions," Corrosion, vol. 63, no. 2, pp. 135144, 2007.

[18] K. Demirkan, G. E. Derkits Jr., D. A. Fleming et al., "Corrosion of Cu under highly corrosive environments," Journal of the Electrochemical Society, vol. 157, no. 1, pp. C30-C35, 2010. 

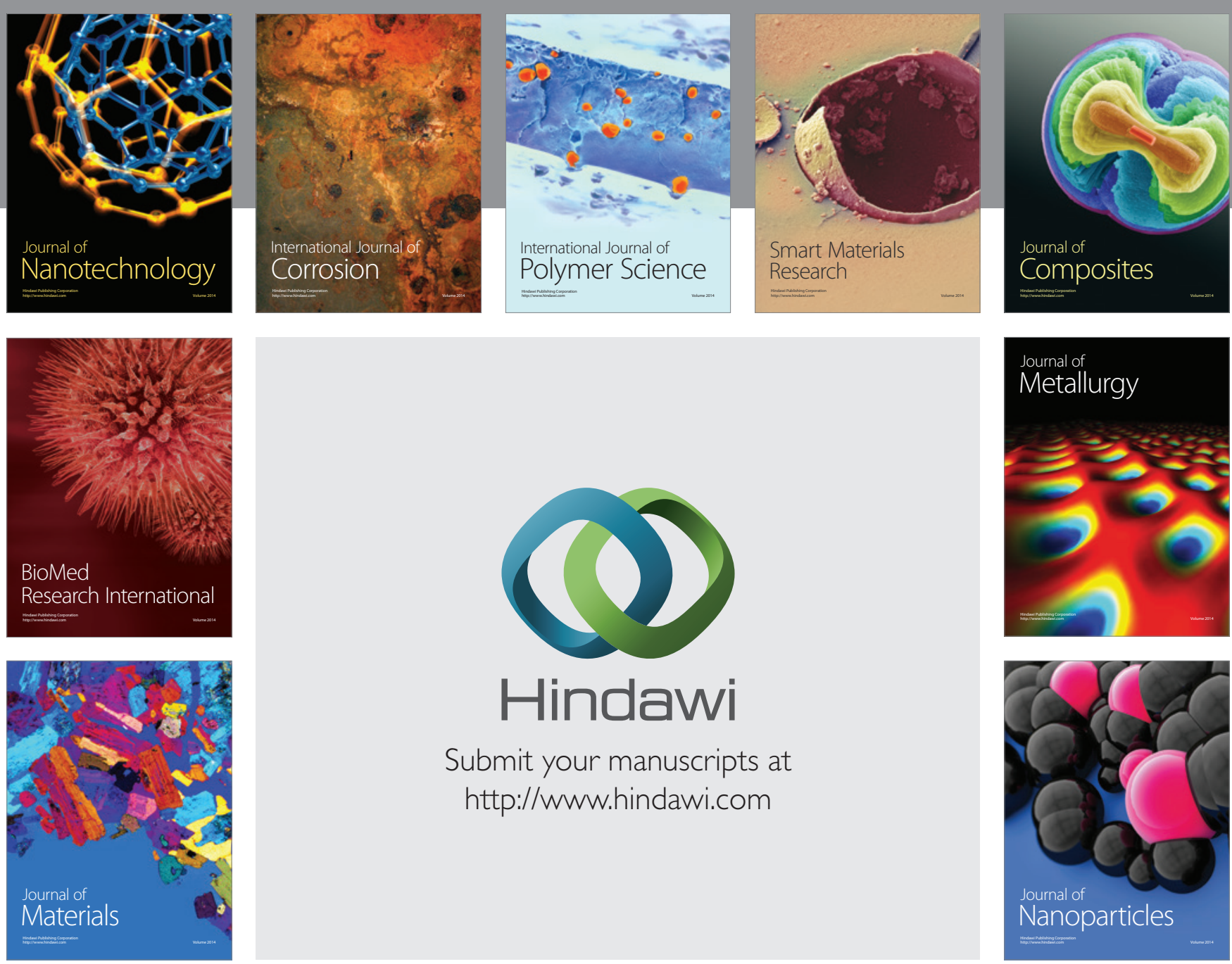

Submit your manuscripts at http://www.hindawi.com
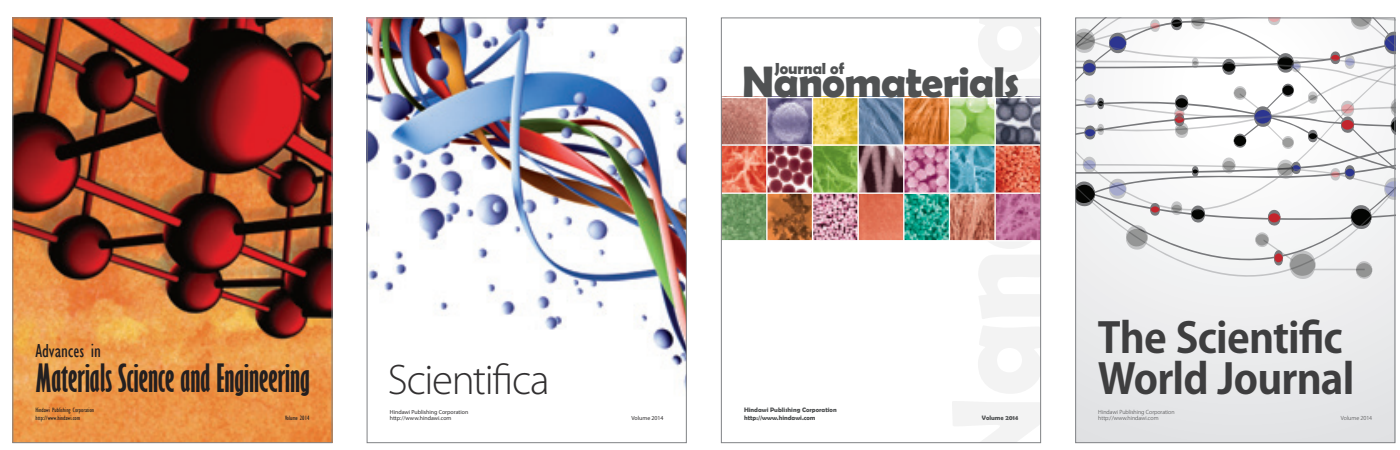

\section{The Scientific World Journal}
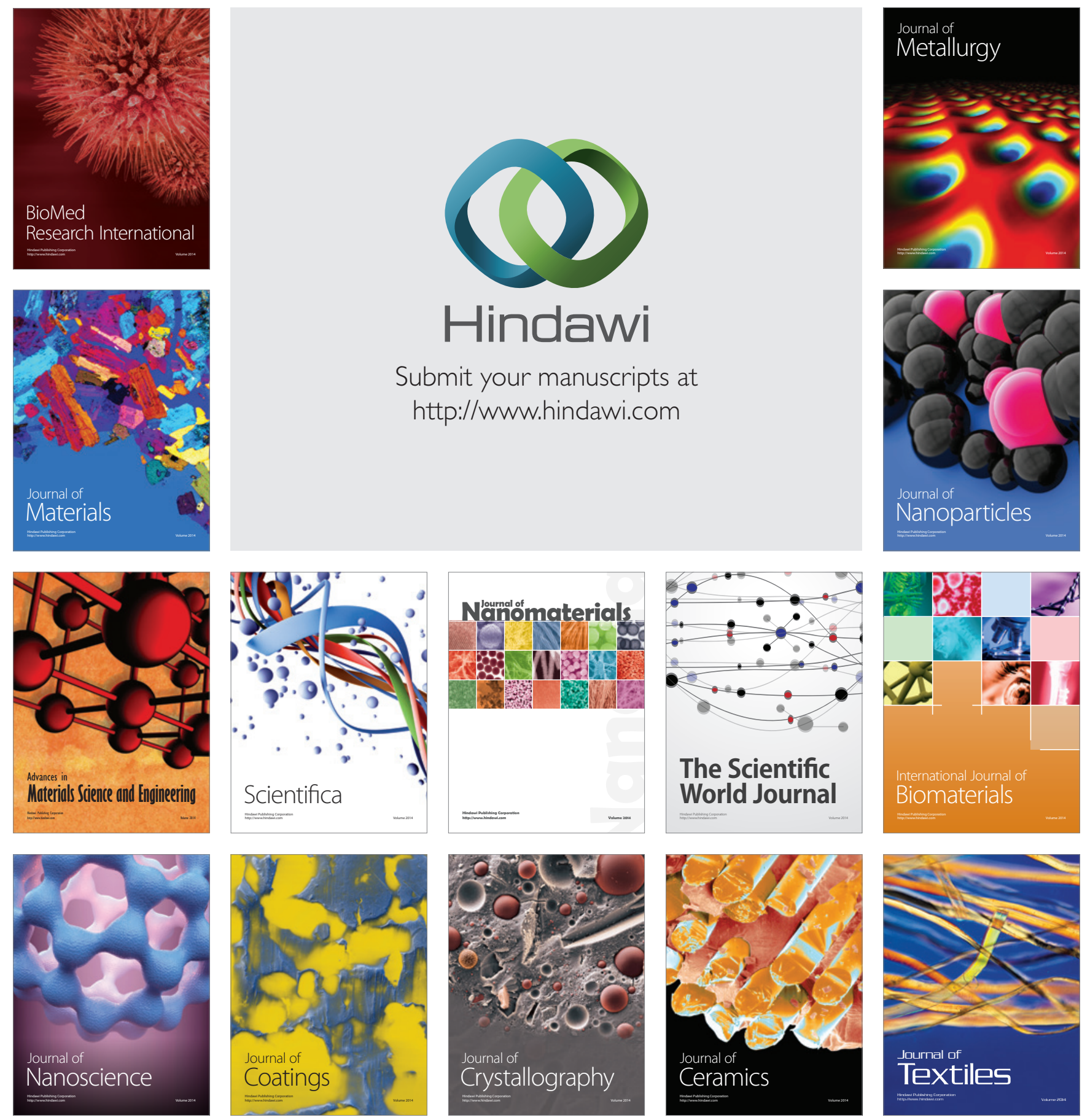